\title{
Prenatal development toxicity study of zinc oxide nanoparticles in rats
}

\author{
This article was published in the following Dove Press journal: \\ International Journal of Nanomedicine \\ 15 December 2014 \\ Number of times this article has been viewed
}

\author{
Jeong-Sup Hong ${ }^{1,2}$ \\ Myeong-Kyu Park' \\ Min-Seok Kim' \\ Jeong-Hyeon Lim' \\ Gil-Jong Park' \\ Eun-Ho Maeng' \\ Jae-Ho Shin ${ }^{3}$ \\ Meyoung-Kon $\mathrm{Kim}^{4}$ \\ Jayoung Jeong ${ }^{5}$ \\ Jin-A Park ${ }^{2}$ \\ Jong-Choon $\mathrm{Kim}^{6}$ \\ Ho-Chul Shin ${ }^{2}$ \\ 'Health Care Research Laboratory, \\ Korea Testing and Research \\ Institute, Gimpo, South Korea; \\ ${ }^{2}$ College of Veterinary Medicine, \\ Konkuk University, Seoul, South \\ Korea; ${ }^{3}$ Department of Biomedical \\ Laboratory Science, Eulji University, \\ Seongnam-si, South Korea; \\ ${ }^{4}$ Department of Biochemistry and \\ Molecular Biology, Korea University \\ Medical School and College, Seoul, \\ South Korea; ${ }^{5}$ Toxicological Research \\ Division, National Institute of \\ Food and Drug Safety Evaluation, \\ Chungcheongbuk-do, South Korea; \\ ${ }^{6}$ College of Veterinary Medicine, \\ Chonnam National University, \\ Gwangju, South Korea
}

Correspondence: Ho-Chul Shin Department of Veterinary Pharmacology and Toxicology, College of Veterinary Medicine, Konkuk University,

Hwayang-dong I, Kwangjin-gu,

Seoul I43-70I, South Korea

Tel +82 24504056

Fax +82 24503037

Email hshin@konkuk.ac.kr
Abstract: This study investigated the potential adverse effects of zinc oxide nanoparticles ([ZnO $\left.{ }^{\mathrm{SM} 20(+)} \mathrm{NPs}\right]$ zinc oxide nanoparticles, positively charged, $20 \mathrm{~nm}$ ) on pregnant dams and embryo-fetal development after maternal exposure over the period of gestational days 5-19 with Sprague-Dawley rats. $\mathrm{ZnO}^{\mathrm{SM} 20(+)} \mathrm{NPs}$ were administered to pregnant rats by gavage at $0,100,200$, and $400 \mathrm{mg} / \mathrm{kg} / \mathrm{day}$. All dams were subjected to a cesarean section on gestational day 20 , and all of the fetuses were examined for external, visceral, and skeletal alterations. Toxicity in the dams manifested as significantly decreased body weight after administration of $400 \mathrm{mg} / \mathrm{kg} /$ day NPs; reduced food consumption after administration of 200 and $400 \mathrm{mg} / \mathrm{kg} /$ day NPs; and decreased liver weight and increased adrenal glands weight after administration of $400 \mathrm{mg} / \mathrm{kg}$ /day NPs. However, no treatment-related difference in: number of corpora lutea; number of implantation sites; implantation rate (\%); resorption; dead fetuses; litter size; fetal deaths and placental weights; and sex ratio were observed between the groups. On the other hand, significant decreases between treatment groups and controls were seen for fetal weights after administration of $400 \mathrm{mg} / \mathrm{kg} /$ day NPs. Morphological examinations of the fetuses demonstrated significant differences in incidences of abnormalities in the group administered $400 \mathrm{mg} / \mathrm{kg} /$ day. Meanwhile, no significant difference was found in the $\mathrm{Zn}$ content of fetal tissue between the control and high-dose groups. These results showed that oral doses for the study with 15-days repeated of $\mathrm{ZnO}^{\mathrm{SM} 20(+)} \mathrm{NPs}$ were maternotoxic in the $200 \mathrm{mg} / \mathrm{kg} /$ day group, and embryotoxic in the $400 \mathrm{mg} / \mathrm{kg} /$ day group.

Keywords: developmental toxicity, maternal toxicity, nanotoxicology, teratogenicity

\section{Introduction}

Recent advances in nanotechnology have spurred increases in the use of nanoparticles (NPs), and concerns over the possible detrimental effects associated with exposure to NPs. ${ }^{1}$ Zinc oxide nanoparticles (ZnO NPs) are currently engineered and most widely used NPs. Most applications with $\mathrm{ZnO}$ powder exploit the reactivity of the oxide, as a precursor to other zinc compounds. ${ }^{2}$ The applications in material science utilize the high refractive index, high thermal conductivity, and binding properties of $\mathrm{ZnO}$. Possible exposure to $\mathrm{ZnO}$ NPs could occur in the industrial settings and through everyday consumer products. ZnO NPs are added into diverse materials and products, such as plastics, ceramics, glass, cement, rubber, lubricants, paints, ointments, adhesive, sealants, pigments, batteries, ferrites, and fire retardants. In addition, $\mathrm{ZnO}$ nanomaterials possess ultraviolet (UV)-shielding, antibacterial properties, deodorizing effects, and heat and UV light resistance, which could provide many great potentials for a wide range of applications in many fields: cosmetics and sunscreens, ${ }^{3}$ food additives, additives in packing, ${ }^{4,5}$ fungicides in agriculture ${ }^{6}$ and biomedical applications such as anticancer drugs. ${ }^{7,8}$ However, the human risk and toxicity mechanism are not well known. 
Since zinc is an essential trace element in the human body and is commonly present in foods or added as a nutritional supplement, $\mathrm{ZnO}$ is generally considered to be a material with low toxicity. ${ }^{9}$ However, $\mathrm{ZnO}$ could turn into hazardous material upon inhalation as a gas (for example, metal fume fever), since fumes could be generated from melting and oxidizing at high temperature from zinc or zinc alloys. ${ }^{9}$ Drinker et $\mathrm{a}^{10}$ and Balance et $\mathrm{al}^{11}$ reported that higher concentrations of freshly generated $\mathrm{ZnO}$, as given in previous human inhalation exposure studies, can produce symptomatic, physiologic, and hematologic effects, as well as elevations in certain peripheral blood and bronchoalveolar lavage cytokines. It should be noted that small-sized particles are more reactive and responsive than bulk-sized particles, because they have a higher proportion of atoms on their surface. ${ }^{12}$ Also, due to the lower surface energy of ZnO NPs, they can be well dispersed in various solvents as well as in air. ${ }^{13}$ Therefore, exposures and uptakes of ZnO NPs could occur through various routes.

Few reports were published on the diverse biological systems of ZnO NPs. ${ }^{13,14}$ Severe damages to liver and lung tissues from acute inhalation of ZnO NPs at dose of $2.5 \mathrm{mg} / \mathrm{kg}$ body weight in Wistar rats were reported by Wang et al. ${ }^{14}$ Also, nano-forms of various particles were more toxic than their micro-counterparts after acute exposure via the oral route in mice..$^{15}$ In an another study by Wang et al, acute oral toxicity study in mice of ZnO NPs at a high dose range ( $1-5 \mathrm{~g} / \mathrm{kg}$ body weight) revealed the increased damages to liver, spleen, and pancreas with increased doses. ${ }^{16}$ In the dermal toxicity study, 28-day repeated dose of $\mathrm{ZnO}$ NPs caused the greater collagen losses in skin of Sprague-Dawley (SD) rats in comparison with tail. ${ }^{17}$ Liver, lung, and kidney were considered to be the main target organs in a pharmacokinetic and tissue distribution study. ${ }^{18}$ Also, Lu et al ${ }^{19}$ suggested that ZnO NPs could disturb the energy metabolisms and cause impairments in mitochondria and cell membrane of rat kidney, in causing ZnO NPsinduced nephrotoxicity. In spite of significant impact of increased usages and productions of ZnO NPs to human health and the environment, the potential adverse effects of ultrafine $\mathrm{ZnO}$ on pregnant dams and embryo-fetal development have never been determined.

Currently, there is a serious lack of information on the potential NP hazard to human health, particularly on their possible toxic effects on the endocrine system, and existing data and knowledge of potential endocrine interactions and toxicities are quite limited (for example, reprotoxicity). ${ }^{20,21}$ Some studies of reproductive function suggest that exposure to some nanomaterials may disrupt endocrine functions such as regulation of serum sex-hormone levels. In contrast, other nanomaterials may prevent endocrine dysfunction via various mechanisms, including antioxidant effects. ${ }^{20} \mathrm{Also}$, a lot of evidence shows that fetuses are affected more than adults by a variety of environmental toxins because of physiological immaturity. Yamashita et $\mathrm{al}^{21}$ reported that nanosilica induced fetal resorption and restricted fetal growth, and surface modification of nanosilica with carboxyl or amine groups prevented resorption and fetal growth restriction in the study of nanosilica $(70 \mathrm{~nm})$.

Therefore, studies of reproductive function are necessary to evaluate the potential endocrine-disrupting risks and the effects on fetuses and pregnancies of nanomaterials. The present study was undertaken to investigate the potential adverse effects of 20-nm positively charged $\mathrm{ZnO}$ NPs $\left(\mathrm{ZnO}^{\mathrm{SM20(+)}}\right.$ NPs) on pregnant dams and embryo-fetal development in SD rats. The results of this investigation could provide additional relevant information to the safety evaluation of $\mathrm{ZnO}^{\mathrm{SM} 20(+)} \mathrm{NP}$ exposures during pregnancy in SD rats.

\section{Materials and methods}

This study was performed in compliance with Organization for Economic Cooperation and Development (OECD) test guideline 414 entitled to Prenatal Developmental Toxicity Study, ${ }^{22}$ and in accordance with the Good Laboratory Practice (GLP) principle. ${ }^{23,24}$ The GLP process was performed in accordance with the standard operation procedures certified by the Ministry of Food and Drug Safety (MFDS). All of the animals were cared for as specified in the "Guide for the Care and Use of Laboratory Animals" issued by the Animal Care and Use Committee of the NVRQS (National Veterinary Research and Quarantine Service).

\section{Characterization of $\mathrm{ZnO}$ NPs}

$\mathrm{ZnO}^{\mathrm{SM} 20} \mathrm{NPs}$ (Lot No 141319 for $20 \mathrm{~nm}$ ), supplied by Sumitomo-Osaka Cement Co. (Tokyo, Japan), had $100.1 \%$ assay analysis and also contained $<1 \mathrm{ppm} F e$ not detected and $1.5 \mathrm{ppm}$ arsenic trioxide (As2O3). The ZnO NPs were capped with L-serine molecules, which are widely used capping agents for in organic NPs, providing charge surface property. ${ }^{25-27}$

\section{Animals and dosage}

$\mathrm{Crl}: \mathrm{CD}(\mathrm{SD})$ rats are commonly used in toxicity studies, as they have a large amount of reference data accumulated over a long time. Male and nulliparous female rats at 10 weeks of age were obtained from a specific pathogen-free colony at Orient Bio Inc. (Gyeonggi-do, South Korea) and used after 12 days of quarantine and acclimatization. The animals were 
housed in a room that was maintained at a temperature of $20.8^{\circ} \mathrm{C}-23.0^{\circ} \mathrm{C}$ and a relative humidity of $45.3 \%-56.9 \%$, with artificial lighting from 8 am to $8 \mathrm{pm}$ and 10-15 air changes per hour. Normally, 1:1 (one male to one female) mating was used in this study. Each morning, the female rats were examined for the presence of sperm or a vaginal plug. Day 0 of pregnancy was defined as the day when a vaginal plug or sperm was found. The mated females were housed individually in clear polycarbonate cages with stainless steel wire lids. They were allowed to drink sterilized tap water with UV irradiation and fed on commercial rodent chow (Cargill Agri Purina, Gyeonggi-do, Korea) ad libitum.

For the oral administration of $\mathrm{ZnO}^{\mathrm{SM} 20(+)} \mathrm{NPs}$, the NPs were suspended in $20 \mathrm{nM}$ 4-(2-hydroxyethyl)-1piperazineethanesulfonic acid (HEPES) buffer with $2 \%$ L-serine (vehicle) and then mixed well. The final $\mathrm{pH}$ of the buffer solution was adjusted with hydrochloric acid to 6.5 , and $20 \%$ of the surface-modified $\mathrm{ZnO}^{\text {SM20(+) }} \mathrm{NPs}$ were used as a stock solution. Before the administration, the suspension was stirred for 10 seconds and then diluted with distilled water. Concentration of dosing solution was measured on gestational day (GD) 5, 11, and 19 using inductive coupled plasma atomic emission spectrometry (ICP-AES) (ULTIMA2; HORIBA JOBIN YVON, Paris, France).

The ZnO NPs were administered daily by gavage to pregnant rats from GD 5 through 19 with a dose volume of $10 \mathrm{~mL} / \mathrm{kg}$ body weight. The vehicle control group received only HEPES/L-serine buffer solution with gavage. The daily application volume was calculated in advance based on the most-recently recorded body weight of the individual animal.

\section{Dose-range finding study}

In a previous dose-range finding study, 14-day repeated oral dose of $\mathrm{ZnO}^{\mathrm{SM} 20(+)}$ NPs showed decreases in body weight, and changes in hematology and biochemistry parameters for 1,000- and 2,000-mg/kg/day groups. Death occurred in two male rats from the $2,000-\mathrm{mg} / \mathrm{kg} /$ day group. Decreases in body weight, reductions in food consumption, and changes in hematology and biochemistry parameters were observed from 1,000- and 2,000-mg/kg/day groups. In a subchronic toxicity study of 90-day repeated oral treatment of $\mathrm{ZnO}^{\mathrm{SM} 20(+)}$ NPs, the decreases in food and water consumptions were observed in 125-, 250-, and 500-mg/kg/day groups. Reductions in thymus weight, atrophy of testis and seminal vesicle, and changes of hematology and biochemistry parameters were present in 250- and 500-mg/kg/day groups. Moreover, repeated oral doses of $\mathrm{ZnO}^{\mathrm{SM} 20(+)} \mathrm{NPs}$ caused aninar cell apoptosis, submucosal edema, inflammation in the glandular stomach, and decreases in total protein and albumin for 250 - and 500-mg/kg/day groups. Either single oral dose or 90-day repeated oral doses (vehicle control and 125, 250, and $500 \mathrm{mg} / \mathrm{kg} /$ day) was performed for pharmacokinetic study; the increased zinc concentrations in plasma were seen for $125-, 250-$, and 500-mg/kg/day groups. ${ }^{28}$ Therefore, for the prenatal and developmental toxicity study, the high dose was set to $400 \mathrm{mg} / \mathrm{kg} /$ day of body weight, and the middle and low doses was set to 200 and $100 \mathrm{mg} / \mathrm{kg} / \mathrm{day}$, respectively.

\section{Experimental groups}

A total of 91 healthy female rats were assigned randomly to four experimental groups as follows: three treatment groups of $\mathrm{ZnO}^{\mathrm{SM} 20(+)} \mathrm{NPs}$ receiving $100(\mathrm{n}=24), 200(\mathrm{n}=21)$, and 400 $\mathrm{mg} / \mathrm{kg} /$ day $(\mathrm{n}=23)$, and a vehicle control group (inseminated females per group). The selected doses for this study were based on the results of a dose-range finding study, conducted in our laboratory.

\section{Observation of dams}

All pregnant females were observed daily throughout the gestation period for clinical signs (mortality, morbidity, general appearance, and behavior). Maternal body weights were measured daily from GD 0-20, and individual food consumptions were determined on GD $0,2,4,6,8,10,12$, 14, 16, and 18. At the scheduled termination day (GD 20), all of the pregnant females were euthanized by isoflurane inhalation and exsanguination from the aorta. A complete gross postmortem examination was then performed. The absolute and relative (organ-to-body weight ratio) weights of the liver, heart, brain, kidneys, ovaries, spleen, lung, uteral cornua, adrenal glands, and pituitary were measured.

\section{Postmortem examination}

The ovaries and uteri of each female were removed and examined for the number of corpora lutea and the status of all the implantation sites, ie, live and dead fetuses, early and late resorptions, and total implantations. Uteri with no evidence of implantation were stained with a $2 \%$ sodium hydroxide solution to identify the presence of early resorption sites. ${ }^{29}$ If no stained implantation site was present, the rat was considered "not pregnant".

On day 20 of gestation, dams were subjected to cesarean section. Following measurement of gravid uterine weight, corpora lutea, implantation, live fetuses, fetal resorptions, 
and dead fetuses were counted and recorded. Based on the results, the following were calculated:

Preimplantation loss $(\%)=\frac{\begin{array}{l}\text { (number of corpora lutea }- \\ \text { number of implantations) }\end{array}}{\text { (number of corpora lutea) }} \times 100$

Postimplantation loss $(\%)=\frac{\begin{array}{l}\text { (number of implantations }- \\ \text { number of live fetuses) }\end{array}}{\text { (number of implantations) }} \times 100(2)$

Fetal death $=$ resorptions + dead fetuses

Resorption was classified as "early" when only a resorption site resembling a dark brown blood clot and with no embryonic tissue was visible, and was considered "late" when both the placental and embryonic tissues were visible at the postmortem examination. All live fetuses were weighed individually, sexed, and examined for any morphological abnormalities, including a cleft palate. Alternate fetuses were selected for either skeletal or visceral examinations. Half of the live fetuses from each litter were fixed in absolute ethanol, eviscerated, and then processed for skeletal staining with alizarin red S and Alcyan blue using for subsequent skeletal examination. ${ }^{30}$ The other half was preserved in Bouin solution and examined for internal softtissue changes using a freehand razor sectioning technique ${ }^{31}$ and Nishimura's method. ${ }^{32}$ The observed fetal morphological alterations in this study were classified as developmental malformations or variations. A malformation was defined as a permanent structural change that is likely to adversely affect survival or health. ${ }^{33}$ The term "variation" was defined as a change that occurred within the normal population under investigation and may be unlikely to adversely affect survival or health. Terminology suggested in an internationally developed glossary of terms was used to classify the structural developmental abnormalities in common laboratory mammals. ${ }^{34}$

\section{Zn concentration in fetal tissue}

To investigate the placenta transfer of $\mathrm{ZnO}^{\mathrm{SM} 20(+)} \mathrm{NPs}$ in vivo, four extra female rats were used in the control (control group; $\mathrm{n}=2$ ) and 400-mg/kg/day groups $\left(\mathrm{ZnO}^{\mathrm{SM} 20(+)} \mathrm{NPs}\right.$; $n=2)$. Dosing occurred for the period of GD 5-19 in the same manner as that for the main study animals. On GD 20 , fetuses were collected via cesarean sections from dams, and $\mathrm{Zn}$ contents in the fetal tissues were analyzed. Fetuses were digested in concentrated nitric acid overnight. The next day, nitric acid and perchloric acid were added to each sample and heated at $200^{\circ} \mathrm{C}-250^{\circ} 5$ until the solutions were colorless and clear. The concentrated sample solutions were transferred into a $100-\mathrm{mL}$ volumetric flask and filled with purified water to the measuring line. Before analysis, ICPAES (HORIBA JOBIN YVON) was calibrated every time by running at least six $\mathrm{Zn}$ standard concentrations $(0.5,2,5$, $10,20$, and $40 \mathrm{mg} / \mathrm{L})$.

\section{Data analysis}

The unit for statistical measurement was the pregnant female or the litter. ${ }^{35}$ Quantitative continuous data, such as the maternal body weight, food consumption, fetal body weight, and placental weight, were subjected to a one-way analysis of variance, and a Scheffe's multiple comparison test was carried out for the significant differences. ${ }^{36}$ The number of corpora lutea, total implantations, live and dead fetuses, and fetal alterations were evaluated statistically by using the Kruskal-Wallis nonparametric analysis of variance, ${ }^{37}$ followed by the Mann-Whitney $U$-test where appropriate. The sex ratio and the proportions of litters with malformations and developmental variations were compared using a chi-square test and Fisher's exact probability test. ${ }^{38}$ Statistical analyses were performed by comparing the treatment groups with the control group using SPSS 19.0 software (IBM Corporation, Armonk, NY, USA). Differences with a $P$-value of 0.05 or lower were considered to be statistically significant.

\section{Results}

\section{Formulations analysis of test article}

Table 1 summarizes the concentrations of dosing solution for $\mathrm{ZnO}^{\mathrm{SM} 20(+)} \mathrm{NPs}$ on GD 5, 11, and 19. Three analyses confirmed that the analyzed concentrations of all dose formulations were within $\pm 15 \%$ of the target concentrations. $\mathrm{ZnO}^{\mathrm{SM} 20(+)}$ NPs were stable for 4 hours at room temperature. Concentrations of total zinc were $9.82 \pm 0.84 \mathrm{mg} / \mathrm{mL}$ (mean \pm standard deviation) for the $100-\mathrm{mg} / \mathrm{kg} /$ day group, $20.04 \pm 1.63 \mathrm{mg} / \mathrm{mL}$ for the $200-\mathrm{mg} / \mathrm{kg} /$ day group, and $40.80 \pm 1.47 \mathrm{mg} / \mathrm{mL}$ for the $400-\mathrm{mg} / \mathrm{kg} /$ day group.

\section{Zn concentration in fetuses}

$\mathrm{Zn}$ concentrations in fetal tissues are shown in Figure 1. The measured total $\mathrm{Zn}$ levels by ICP-AES were $14.44 \pm 0.37$ $\mu \mathrm{g} / \mathrm{g}$ (mean \pm standard deviation) for the control group and $16.47 \pm 2.19 \mu \mathrm{g} / \mathrm{g} \mathrm{Zn}$ for the $400-\mathrm{mg} / \mathrm{kg} /$ day group (Table 2). The $\mathrm{Zn}$ contents in fetuses after in utero exposure to $\mathrm{ZnO}^{\mathrm{SM} 20(+)} \mathrm{NPs}$ was not significantly different from the $\mathrm{Zn}$ contents in control fetuses. 
Table I Formulations analysis of dosing solution for $\mathrm{ZnO}^{\mathrm{SM20(+)}} \mathrm{NPs}$ on gestation day 5 , II, and 19

\begin{tabular}{|c|c|c|c|}
\hline \multirow[t]{2}{*}{ Dosing date } & \multicolumn{3}{|l|}{$\mathrm{ZnO}^{\text {SM20(+) NPs }}$} \\
\hline & Target concentration $(\mathrm{mg} / \mathrm{mL})$ & Determined concentration $(\mathrm{mg} / \mathrm{mL})$ & Difference from target (\%) \\
\hline Gestation day 5 & 0 & Not detected & Not detected \\
\hline Gestation day II & 0 & Not detected & Not detected \\
\hline Gestation day 19 & 0 & Not detected & Not detected \\
\hline Gestation day 5 & 10 & 10.03 & 0.31 \\
\hline Gestation day II & 10 & 8.90 & -11.00 \\
\hline \multirow[t]{2}{*}{ Gestation day 19} & 10 & 10.53 & 5.30 \\
\hline & & a9.82 \pm 0.84 & \\
\hline Gestation day 5 & 20 & 20.72 & 3.61 \\
\hline Gestation day II & 20 & 18.18 & -9.10 \\
\hline \multirow[t]{2}{*}{ Gestation day 19} & 20 & 21.22 & 6.10 \\
\hline & & ${ }^{2} 20.04 \pm 1.63$ & \\
\hline Gestation day 5 & 40 & 40.53 & 1.32 \\
\hline Gestation day II & 40 & 42.39 & 5.98 \\
\hline \multirow[t]{2}{*}{ Gestation day 19} & 40 & 39.48 & -1.30 \\
\hline & & ${ }^{\mathrm{a}} 40.80 \pm 1.47$ & \\
\hline
\end{tabular}

Note: ${ }^{\vee}$ Values are expressed as mean \pm standard deviation.

Abbreviations: NPs, nanoparticles; $\mathrm{ZnO}^{\text {SM2O(+) }}$, 20-nm positively charged $\mathrm{ZnO}$.

\section{Effects on dams}

Although seven of 24 dams from the $100-\mathrm{mg} / \mathrm{kg} /$ day group, 12 of 21 dams from the $200-\mathrm{mg} / \mathrm{kg} /$ day group, and 18 of 23 dams from the 400-mg/kg/day group showed salivation around the mouth in general appearance. Starting from 3-12 days after oral administration, alopecia (localized areas of partial alopecia) was observed in one pregnant rat from the $100-\mathrm{mg} / \mathrm{kg} /$ day group, one from the $200-\mathrm{mg} / \mathrm{kg} /$ day group, and one from the $400-\mathrm{mg} / \mathrm{kg} /$ day group (data not shown). This clinical sign was not recovered for the treatment period.

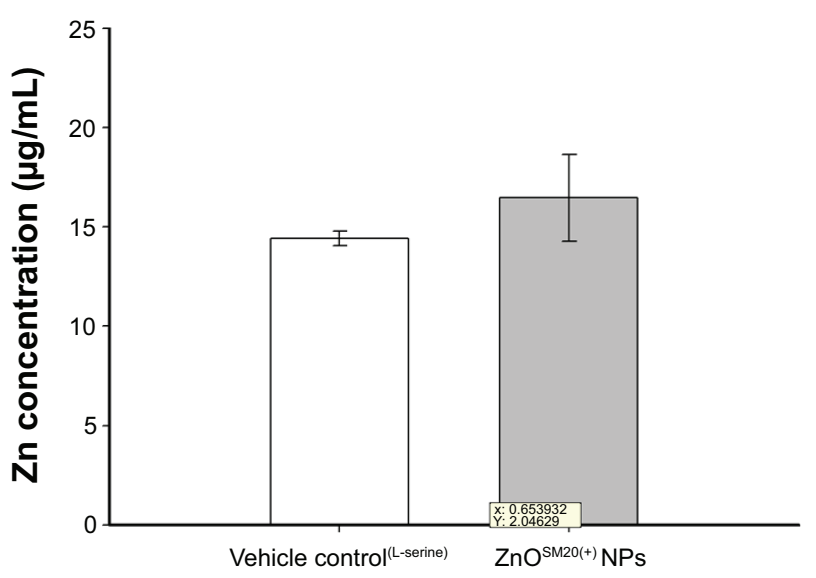

Figure I The total $\mathrm{Zn}$ levels measured with ICP-AES.

Notes: To investigate the placenta transfer of $\mathrm{ZnO}^{\mathrm{SM} 20(+)} \mathrm{NPs}$ in vivo, four extra female rats were used in the control (nontreatment control group; $n=2$ ) and $400-\mathrm{mg} / \mathrm{kg} /$ day $\left(\mathrm{ZnO}^{\mathrm{SM} 20(+)} \mathrm{NPs} ; \mathrm{n}=2\right)$ groups. Dosing occurred on gestational day 5-19 in the same manner as for main study animals.

Abbreviations: ICP-AES, inductive coupled plasma atomic emission spectrometry; $\mathrm{ZnO}^{\mathrm{SM} 20(+)} \mathrm{NPs}$, 20-nm positively charged $\mathrm{ZnO}$ nanoparticles.
The changes in body weight during the entire experimental period are listed in Figure 2. As shown by the data in Table 3 , significant decreases in maternal body weight on GD 20 from the high-dose group was observed in comparison with the vehicle control group. The maternal-body-weight gain during pregnancy and corrected body weight were also significantly lower in the high-dose group than in the control group. Statistically significant decreases in food consumption were noticed on day 18 of gestation in the 200- and 400-mg/ $\mathrm{kg}$ /day groups in comparison to the vehicle control group (Table 4). At the scheduled autopsy, one case of caveola of kidney surface in the vehicle control group; one case of splenomegaly in the $200-\mathrm{mg} / \mathrm{kg} /$ day group; and hypertrophy of adrenal and lung, edematous bowel, gastro-tympanites, and red reaction of liver in the $400-\mathrm{mg} / \mathrm{kg} /$ day group were observed in dams (data not shown). The absolute and relative organ weights of the pregnant rats treated with $\mathrm{ZnO}^{\mathrm{SM} 20(+)} \mathrm{NPs}$ are presented in Table 5. Significantly decreased absolute liver weight in the $400-\mathrm{mg} / \mathrm{kg} /$ day group was observed, and the increased absolute and relative weights of adrenal gland were significant in the $400-\mathrm{mg} / \mathrm{kg} / \mathrm{day}$ group in a dose-dependent manner in comparison with the vehicle control group.

\section{Effects on embryo-fetal development}

Table 6 summarizes the reproductive findings for the pregnant rats treated with $\mathrm{ZnO}^{\mathrm{SM} 20(+)} \mathrm{NPs}$ on GD 5-19. The overall pregnancy rates were similar for all dosage groups, ranging 
Table 2 The $\mathrm{Zn}$ content in fetuses after in utero exposure to $\mathrm{ZnO}^{\mathrm{SM20(+)}} \mathrm{NPs}$

\begin{tabular}{|c|c|c|c|}
\hline \multirow[t]{2}{*}{ Parameters } & \multirow[t]{2}{*}{ Unit } & \multicolumn{2}{|l|}{ Dose (mg/kg bw/day) } \\
\hline & & $\begin{array}{l}\text { Nontreatment control } \\
\text { group }\end{array}$ & $\begin{array}{l}400 \mathrm{mg} / \mathrm{kg} \text { treatment } \\
\left(\mathrm{ZnO}^{\text {SM20(+) }} \mathrm{NPs}\right)\end{array}$ \\
\hline Number of fetuses/pregnant females & (fetus) & $28 / 2$ & $28 / 2$ \\
\hline \multirow[t]{3}{*}{ Analyzed concentration } & $(\mu \mathrm{g} / \mathrm{mL})$ & 9.04 & 8.94 \\
\hline & $(\mu \mathrm{g} / \mathrm{mL})$ & 6.77 & 8.82 \\
\hline & $(\mu \mathrm{g} / \mathrm{mL})$ & a7.91 \pm 1.61 & a $8.88 \pm 0.08$ \\
\hline Dilution & & 100.00 & 100.00 \\
\hline \multirow[t]{3}{*}{ Sample weight } & $(g)$ & 63.75 & 49.60 \\
\hline & $(g)$ & 46.05 & 59.10 \\
\hline & $(\mathrm{g})$ & a54.90 \pm 0.37 & a54.35 \pm 6.72 \\
\hline \multirow[t]{3}{*}{ Conversion concentration } & $(\mu g / g)$ & 14.18 & 18.02 \\
\hline & $(\mu g / g)$ & 14.70 & 14.92 \\
\hline & $(\mu g / g)$ & a $4.44 \pm 0.37$ & $\mathrm{a} 16.47 \pm 2.19$ \\
\hline
\end{tabular}

Note: a Values are expressed as mean \pm standard deviation.

Abbreviations: bw, body weight; NPs, nanoparticles; $\mathrm{ZnO}^{\text {SM20(+) }}, 20-\mathrm{nm}$ positively charged $\mathrm{ZnO}$.

from $87.5 \%-100 \%$. Totally resorbed litters were not found in any group. The number of corpora lutea, implantations, and fetal deaths, as well as implantation rates, placental weight, and sex ratios of the live fetuses were similar for the treatment groups and the vehicle control group. Significantly decreased fetal weights of males and females were observed in the $400-\mathrm{mg} / \mathrm{kg} /$ day group in comparison to the vehicle control group. No fetus showed an external malformation. Hematoma was shown in all groups, including the vehicle control group. However, the numbers of fetuses with hematomas were not significantly increased in comparison to the control group (Table 7). Several types of visceral variations were seen in fetuses of the treatment groups, including misshapen thymus, ureter abnormality (grade I: slight dilation of the renal pelvis, grade II: reduced papilla size and noticeable dilation of the renal pelvis, grade III: very short or no papillae and a

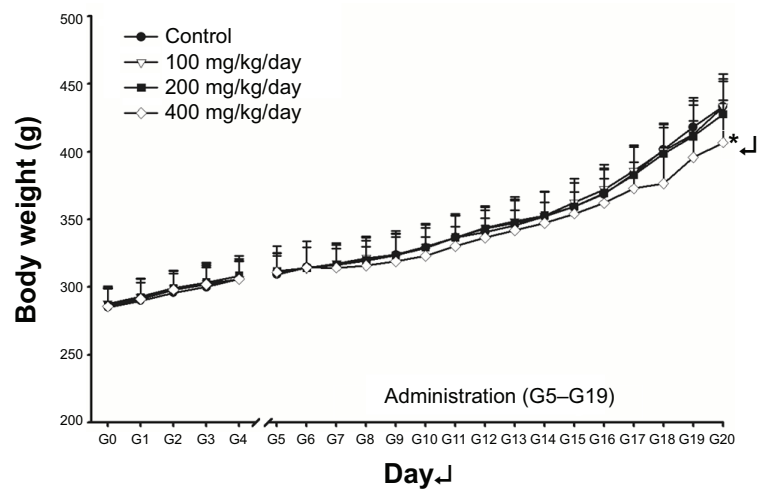

Figure 2 Body weight changes of female rats during the gestation period.

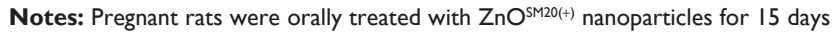
(G5-GI9) with dose of 100,200 , and $400 \mathrm{mg} / \mathrm{kg} /$ day. "G" refers to the number of the days after gestation. "G0" refers to the day on which a rat becomes pregnant. Statistically different from the vehicle control group; $* P<0.05$. marked dilation of the renal space), ${ }^{39}$ dilated renal pelvis, and urinary bladder hypertrophy (Table 8 ). There were significant increases in the number of fetuses with visceral variations, such as misshapen thymus, ureter abnormality (grade III), and ectopic kidney in the 400-mg/kg/day group. Table 9 reveals the types and incidences of fetal skeletal malformations and variations. Skeletal malformation, such as cleavage ossification of thoracic centrum, was observed in all groups. Although several types of skeletal variations were observed, including incomplete ossification of skull, dumbbell ossification of thoracic centrum, incomplete ossification of thoracic centrum, asymmetric thoracic centrum, supernumerary rib, short rib, and incomplete ossification of sternebra, no significant difference in the number of fetuses with skeletal variations or in the number of affected fetuses was seen between the groups.

\section{Discussion}

Recently, information on the toxicity of ZnO NPs, including liver damage, membrane injury, cytotoxicity, and inflammatory response, ${ }^{40,41}$ has been accumulating, but nearly no extensive study on the reproduction and developmental toxicity in mammals was performed. Many studies have been conducted on $\mathrm{ZnO}$ NP toxicity, in both environmental species and mammalian cell lines. ${ }^{42-44}$ On the other hand, $\mathrm{ZnO}$ NPs are used extensively in various commercial applications, ${ }^{45,46}$ since nanomaterials have specific physicochemical and electrical properties. ${ }^{47}$ As $\mathrm{ZnO}$ NPs become a significant source for intended and unintended human exposures, it would be highly desirable and necessary to know more about other possible toxicities of ZnO NPs. This study was conducted to investigate the maternal and developmental toxic potentials of $\mathrm{ZnO}^{\mathrm{SM} 20(+)} \mathrm{NPs}$ after 
Table 3 Body weights of the pregnant rats treated with $\mathrm{ZnO}^{\mathrm{SM20(+)}} \mathrm{NPs}$

\begin{tabular}{|c|c|c|c|c|}
\hline \multirow[t]{2}{*}{ Dose (mg/kg bw/day) } & \multicolumn{4}{|c|}{$\mathrm{ZnO}^{\mathrm{SM} 20(+)} \mathrm{NPs}$} \\
\hline & Vehicle( ${ }^{\text {(Serine) }}$ & 100 & 200 & 400 \\
\hline Number of pregnant females & 23 & 24 & 21 & 23 \\
\hline Gestation day 0 & $284.9 \pm 13.83$ & $287.7 \pm 11.68$ & $286.8 \pm 13.78$ & $285.5 \pm 14.09$ \\
\hline Gestation day I & $289.9 \pm 13.49$ & $292.9 \pm 13.43$ & $292.5 \pm 13.33$ & $291.2 \pm 12.14$ \\
\hline Gestation day 2 & $295.9 \pm \mid 4.27$ & $299.0 \pm 13.36$ & $299.0 \pm 13.40$ & $298.1 \pm 13.76$ \\
\hline Gestation day 3 & $300.0 \pm 14.45$ & $302.8 \pm 15.03$ & $303.4 \pm 13.82$ & $301.9 \pm 13.83$ \\
\hline Gestation day 4 & $306.1 \pm 14.87$ & $305.7 \pm 13.63$ & $308.3 \pm 14.68$ & $305.7 \pm 13.22$ \\
\hline Gestation day 5 & $309.3 \pm|5.6|$ & $3|0.4 \pm| 2.7 \mid$ & $311.6 \pm 18.68$ & $311.1 \pm 14.13$ \\
\hline Gestation day 6 & $314.5 \pm 15.02$ & $313.8 \pm 15.55$ & $314.0 \pm 15.24$ & $314.3 \pm 19.58$ \\
\hline Gestation day 7 & $316.1 \pm 15.00$ & $317.4 \pm 15.29$ & $3|6.3 \pm| 4.7 \mid$ & $314.2 \pm 14.19$ \\
\hline Gestation day 8 & $319.2 \pm 15.24$ & $321.4 \pm 16.11$ & $319.6 \pm 16.90$ & $315.9 \pm 13.88$ \\
\hline Gestation day 9 & $323.5 \pm 15.84$ & $324.0 \pm 17.25$ & $323.3 \pm 16.12$ & $318.9 \pm 18.16$ \\
\hline Gestation day 10 & $328.9 \pm 14.95$ & $329.7 \pm 16.96$ & $329.2 \pm 16.85$ & $323.0 \pm 14.10$ \\
\hline Gestation day II & $336.6 \pm 16.16$ & $336.3 \pm 16.88$ & $336.6 \pm 17.42$ & $330.3 \pm|4.4|$ \\
\hline Gestation day 12 & $340.5 \pm 16.05$ & $343.5 \pm 15.62$ & $343.0 \pm 16.79$ & $336.4 \pm 14.52$ \\
\hline Gestation day 13 & $345.6 \pm 18.11$ & $348.6 \pm 18.12$ & $347.4 \pm 17.24$ & $341.8 \pm 15.02$ \\
\hline Gestation day 14 & $352.2 \pm 17.94$ & $352.5 \pm 17.93$ & $352.8 \pm 17.63$ & $347.2 \pm 15.22$ \\
\hline Gestation day 15 & $359.3 \pm 17.82$ & $362.5 \pm 17.63$ & $359.4 \pm 17.70$ & $354.2 \pm 15.76$ \\
\hline Gestation day 16 & $368.7 \pm 18.36$ & $372.1 \pm 18.35$ & $369.4 \pm 18.22$ & $362.0 \pm 18.06$ \\
\hline Gestation day 17 & $383.6 \pm 21.07$ & $385.7 \pm|8.8|$ & $382.7 \pm 20.61$ & $372.7 \pm 19.66$ \\
\hline Gestation day 18 & $401.6 \pm 19.29$ & $400.7 \pm 19.25$ & $398.4 \pm 21.82$ & $383.9 \pm 22.36$ \\
\hline Gestation day 19 & $4|8.1 \pm 2| .85$ & $4 \mid 2.9 \pm 24.62$ & $411.4 \pm 22.89$ & $395.7 \pm 26.98$ \\
\hline Gestation day 20 & $433.3 \pm 23.90$ & $433.2 \pm 20.68$ & $427.6 \pm 24.53$ & $406.7 \pm 31.27^{*}$ \\
\hline Weight gain during pregnancy & $148.4 \pm 16.58$ & $\mid 45.5 \pm 14.30$ & $140.8 \pm 19.99$ & $121.2 \pm 27.23 * *$ \\
\hline Corrected body weight & $349.0 \pm 21.11$ & $346.8 \pm 18.87$ & $342.3 \pm 22.09$ & $325.5 \pm 26.35^{*}$ \\
\hline Gravid uterine weight & $84.3 \pm 11.63$ & $86.5 \pm 7.50$ & $85.3 \pm 8.02$ & $81.2 \pm 11.30$ \\
\hline
\end{tabular}

Notes: Values are expressed as mean \pm standard deviation. Statistically different from the vehicle control group; $* P<0.05$, $* * P<0.0$ I.

Abbreviations: bw, body weight; NPs, nanoparticles; $\mathrm{ZnO}^{\mathrm{SM} 20(+)}, 20-\mathrm{nm}$ positively charged $\mathrm{ZnO}$.

oral treatment in SD rats at dose levels of 0, 100, 200, and $400 \mathrm{mg} / \mathrm{kg} /$ day from days 5 through 19 of pregnancy. The ZnO NPs were capped with organic ligands, L-serine molecules, which are widely used capping agents for inorganic NPs to enhance the surface charge property. ${ }^{25-27}$
The results showed that a 15 -day repeated oral dosing of $\mathrm{ZnO}^{\mathrm{SM} 20(+)} \mathrm{NPs}$ during pregnancy resulted in maternal toxicity at $400 \mathrm{mg} / \mathrm{kg} / \mathrm{day}$, but the same dose did not cause serious teratogenic toxicity. Although salivation was observed in all treated groups, it was not considered to be related to the

Table 4 Food consumptions of the pregnant rats treated with $\mathrm{ZnO}^{\mathrm{SM20(+)}} \mathrm{NPs}$

\begin{tabular}{|c|c|c|c|c|}
\hline \multirow[t]{2}{*}{ Dose (mg/kg bw/day) } & \multicolumn{4}{|c|}{$\mathrm{ZnO}^{\mathrm{SM} 20(+)} \mathrm{NPs}$} \\
\hline & Vehicle(Serine) & 100 & 200 & 400 \\
\hline Number of pregnant females & 23 & 24 & 21 & 23 \\
\hline Gestation day 0 & $22.56 \pm 3.59$ & $23.69 \pm 3.53$ & $23.00 \pm 2.51$ & $23.77 \pm 8.43$ \\
\hline Gestation day 2 & $27.04 \pm 3.00$ & $26.4 I \pm 3.65$ & $27.64 \pm 2.48$ & $29.07 \pm 7.40$ \\
\hline Gestation day 4 & $28.53 \pm 6.45$ & $26.77 \pm 4.08$ & $27.25 \pm 2.72$ & $29.76 \pm 10.89$ \\
\hline Gestation day 6 & $26.21 \pm 3.85$ & $25.55 \pm 2.67$ & $24.93 \pm 3.86$ & $23.03 \pm 4.00$ \\
\hline Gestation day 8 & $28.40 \pm 7.89$ & $26.75 \pm 3.59$ & $27.11 \pm 3.80$ & $27.06 \pm 4.73$ \\
\hline Gestation day 10 & $29.19 \pm 6.28$ & $27.11 \pm 5.29$ & $28.22 \pm 4.97$ & $25.83 \pm 3.50$ \\
\hline Gestation day 12 & $28.19 \pm 3.01$ & $28.59 \pm 3.26$ & $27.97 \pm 3.55$ & $27.33 \pm 3.40$ \\
\hline Gestation day 14 & $28.54 \pm 2.84$ & $27.93 \pm 3.18$ & $26.90 \pm 3.85$ & $27.56 \pm 5.55$ \\
\hline Gestation day 16 & $31.38 \pm 3.90$ & $30.35 \pm 4.27$ & $29.43 \pm 5.79$ & $28.39 \pm 6.82$ \\
\hline Gestation day 18 & $31.55 \pm 3.60$ & $29.39 \pm 4.84$ & $26.21 \pm 4.17^{*}$ & $25.87 \pm 4.75^{*}$ \\
\hline
\end{tabular}

Notes: Values are expressed as mean \pm standard deviation. Statistically different from the vehicle control group; $* P<0.05$.

Abbreviations: bw, body weight; NPs, nanoparticles; $\mathrm{ZnO}^{\mathrm{SM} 20(+)}, 20-\mathrm{nm}$ positively charged $\mathrm{ZnO}$. 
Table 5 Absolute and relative organ weights of pregnant rats treated with $\mathrm{ZnO}^{\mathrm{SM20(+)}} \mathrm{NPs}$

\begin{tabular}{|c|c|c|c|c|c|}
\hline \multirow[t]{2}{*}{ Dose (mg/kg bw/day) } & \multirow[t]{2}{*}{ Unit } & \multicolumn{4}{|c|}{$\mathrm{ZnO}^{\mathrm{SM} 20(+)} \mathrm{NPs}$} \\
\hline & & Vehicle(Serine) & 100 & 200 & 400 \\
\hline Number of pregnant females & & 23 & 24 & 21 & 23 \\
\hline Body weight at term (g) & & $433.3 \pm 23.90$ & $433.2 \pm 20.68$ & $427.6 \pm 24.53$ & $406.7 \pm 31.27$ \\
\hline \multirow[t]{2}{*}{ Liver } & (g) & $15.63 \pm 1.46$ & $15.85 \pm 1.16$ & $15.09 \pm 1.22$ & $14.22 \pm 1.40 *$ \\
\hline & $(g \%)$ & $3.60 \pm 0.22$ & $3.66 \pm 0.20$ & $3.53 \pm 0.20$ & $3.50 \pm 0.29$ \\
\hline \multirow[t]{2}{*}{ Kidney, left } & $(g)$ & $1.07 \pm 0.07$ & $1.07 \pm 0.07$ & $1.05 \pm 0.08$ & $1.05 \pm 0.08$ \\
\hline & $(\mathrm{g} \%)$ & $0.25 \pm 0.02$ & $0.25 \pm 0.02$ & $0.25 \pm 0.02$ & $0.26 \pm 0.03$ \\
\hline \multirow[t]{2}{*}{ Kidney, right } & $(g)$ & $\mathrm{I} .1 \mathrm{I} \pm 0.07$ & $1.08 \pm 0.07$ & $1.06 \pm 0.09$ & $1.07 \pm 0.09$ \\
\hline & $(g \%)$ & $0.26 \pm 0.02$ & $0.25 \pm 0.02$ & $0.25 \pm 0.02$ & $0.26 \pm 0.03$ \\
\hline \multirow[t]{2}{*}{ Spleen } & $(\mathrm{g})$ & $0.68 \pm 0.15$ & $0.61 \pm 0.16$ & $0.72 \pm 0.16$ & $0.63 \pm 0.13$ \\
\hline & $(\mathrm{g} \%)$ & $0.16 \pm 0.03$ & $0.14 \pm 0.04$ & $0.17 \pm 0.04$ & $0.15 \pm 0.04$ \\
\hline \multirow[t]{2}{*}{ Adrenal gland, left } & $(g)$ & $0.043 \pm 0.008$ & $0.049 \pm 0.010$ & $0.046 \pm 0.010$ & $0.050 \pm 0.010$ \\
\hline & $(g \%)$ & $0.010 \pm 0.002$ & $0.01 \mathrm{I} \pm 0.003$ & $0.011 \pm 0.002$ & $0.012 \pm 0.003^{*}$ \\
\hline \multirow[t]{2}{*}{ Adrenal gland, right } & $(g)$ & $0.04 I \pm 0.008$ & $0.044 \pm 0.010$ & $0.045 \pm 0.007$ & $0.05 I \pm 0.014 *$ \\
\hline & $(\mathrm{g} \%)$ & $0.009 \pm 0.002$ & $0.010 \pm 0.002$ & $0.011 \pm 0.002$ & $0.013 \pm 0.005 * *$ \\
\hline \multirow[t]{2}{*}{ Ovary, left } & (g) & $0.065 \pm 0.013$ & $0.07 I \pm 0.019$ & $0.073 \pm 0.015$ & $0.064 \pm 0.016$ \\
\hline & $(g \%)$ & $0.015 \pm 0.003$ & $0.016 \pm 0.004$ & $0.017 \pm 0.004$ & $0.016 \pm 0.005$ \\
\hline \multirow[t]{2}{*}{ Ovary, right } & (g) & $0.066 \pm 0.014$ & $0.064 \pm 0.017$ & $0.067 \pm 0.012$ & $0.071 \pm 0.014$ \\
\hline & (g\%) & $0.015 \pm 0.003$ & $0.015 \pm 0.004$ & $0.016 \pm 0.003$ & $0.018 \pm 0.004$ \\
\hline \multirow[t]{2}{*}{ Brain } & $(\mathrm{g})$ & $2.05 \pm 0.18$ & $2.0 \mathrm{I} \pm 0.07$ & $2.00 \pm 0.08$ & $1.96 \pm 0.13$ \\
\hline & $(\mathrm{g} \%)$ & $0.47 \pm 0.05$ & $0.46 \pm 0.02$ & $0.47 \pm 0.03$ & $0.48 \pm 0.03$ \\
\hline \multirow[t]{2}{*}{ Pituitary gland } & $(g)$ & $0.015 \pm 0.004$ & $0.015 \pm 0.003$ & $0.016 \pm 0.003$ & $0.014 \pm 0.004$ \\
\hline & $(\mathrm{g} \%)$ & $0.003 \pm 0.001$ & $0.004 \pm 0.001$ & $0.004 \pm 0.001$ & $0.003 \pm 0.001$ \\
\hline \multirow[t]{2}{*}{ Lung } & $(g)$ & $1.36 \pm 0.11$ & $1.35 \pm 0.10$ & $1.39 \pm 0.10$ & $1.32 \pm 0.14$ \\
\hline & $(\mathrm{g} \%)$ & $0.3 I \pm 0.02$ & $0.3 I \pm 0.02$ & $0.32 \pm 0.02$ & $0.33 \pm 0.04$ \\
\hline \multirow[t]{2}{*}{ Heart } & $(g)$ & $1.17 \pm 0.11$ & $1.16 \pm 0.12$ & $1.16 \pm 0.12$ & $1.09 \pm 0.12$ \\
\hline & $(\mathrm{g} \%)$ & $0.27 \pm 0.03$ & $0.27 \pm 0.02$ & $0.27 \pm 0.03$ & $0.27 \pm 0.02$ \\
\hline \multirow[t]{2}{*}{ Uterus (gravid) } & $(g)$ & $84.29 \pm 11.63$ & $86.45 \pm 7.50$ & $85.26 \pm 8.02$ & $81.18 \pm 11.30$ \\
\hline & $(\mathrm{g} \%)$ & $19.44 \pm 2.36$ & $19.97 \pm 1.62$ & $19.95 \pm 1.73$ & $19.95 \pm 2.32$ \\
\hline
\end{tabular}

Notes: Values are expressed as mean \pm standard deviation (g). Statistically different from the vehicle control group; $* \mathrm{P}<0.05, * * \mathrm{P}<0.0 \mathrm{I}$.

Abbreviations: bw, body weight; g\%, relative weight of organ (g) to body weight (g); NPs, nanoparticles; $\mathrm{ZnO}^{\text {SM20(+) }}, 20-\mathrm{nm}^{\mathrm{m}}$ positively charged $\mathrm{ZnO}$.

Table 6 Cesarean section data from pregnant rats treated with $\mathrm{ZnO}^{\mathrm{SM20(+)}} \mathrm{NPs}$

\begin{tabular}{|c|c|c|c|c|}
\hline \multirow[t]{2}{*}{ Dose (mg/kg bw/day) } & \multicolumn{4}{|c|}{$\mathrm{ZnO}^{\mathrm{SM20(+)}} \mathrm{NPs}$} \\
\hline & Vehicle ${ }^{\text {(Serine) }}$ & 100 & 200 & 400 \\
\hline Number of dams & 23 & 24 & 21 & 23 \\
\hline Number of corpora lutea & $19.3 \pm 3.66$ & $18.3 \pm 2.94$ & $19.2 \pm 4.58$ & $18.5 \pm 2.11$ \\
\hline Number of implantation sites & $15.3 \pm 1.57$ & $15.9 \pm 1.35$ & $\mid 5.6 \pm 1.43$ & $16.1 \pm 1.76$ \\
\hline Implantation rate (\%) & $81.0 \pm 13.96$ & $88.6 \pm 13.48$ & $84.0 \pm 13.27$ & $87.6 \pm 9.35$ \\
\hline Fetal deaths & $0.6 \pm 1.12$ & $0.6 \pm 0.78$ & $0.9 \pm 0.85$ & $1.3 \pm 3.30$ \\
\hline \multirow{2}{*}{$\begin{aligned} \text { Resorption } & \text { : early } \\
& \text { : late }\end{aligned}$} & $0.5 \pm 1.08$ & $0.3 \pm 0.53$ & $0.5 \pm 0.60$ & $0.3 \pm 0.65$ \\
\hline & $0.0 \pm 0.21$ & $0.3 \pm 0.55$ & $0.3 \pm 0.46$ & $0.2 \pm 0.42$ \\
\hline Dead fetuses & $0.0 \pm 0.00$ & $0.0 \pm 0.20$ & $0.1 \pm 0.44$ & $0.7 \pm 3.33$ \\
\hline Litter size & $14.7 \pm 1.64$ & $15.3 \pm 1.34$ & $\mid 4.8 \pm 1.67$ & $15.5 \pm 1.95$ \\
\hline Male/female & $179 / 159$ & $177 / 19 \mid$ & $|69 /| 4 \mid$ & $173 / 167$ \\
\hline Sex ratio & 1.13 & 0.93 & 1.20 & 1.04 \\
\hline \multirow[t]{2}{*}{ Fetal weight $(\mathrm{g}):$ male } & $4.03 \pm 0.30$ & $3.96 \pm 0.22$ & $4.07 \pm 0.21$ & $3.7 I \pm 0.29 * *$ \\
\hline & $3.85 \pm 0.35$ & $3.78 \pm 0.22$ & $3.87 \pm 0.21$ & $3.57 \pm 0.29 *$ \\
\hline Placental weight $(\mathrm{g})$ & $0.56 \pm 0.13$ & $0.56 \pm 0.05$ & $0.56 \pm 0.07$ & $0.54 \pm 0.06$ \\
\hline
\end{tabular}

Notes: Values are expressed as mean \pm standard deviation. Statistically different from the vehicle control group; $* P<0.05$, $* * P<0.01$.

Abbreviations: bw, body weight; g\%, relative weight of organ (g) to body weight (g); NPs, nanoparticles; $\mathrm{ZnO}^{\mathrm{SM} 20(+)}, 20-\mathrm{nm}$ positively charged $\mathrm{ZnO}$. 
Table 7 External alterations in fetuses from pregnant rats treated with $\mathrm{ZnO}^{\text {SM20(+) }} \mathrm{NPs}$

\begin{tabular}{|c|c|c|c|c|}
\hline \multirow[t]{2}{*}{ Dose (mg/kg bw/day) } & \multicolumn{4}{|c|}{$\mathrm{ZnO}^{\mathrm{SM} 20(+)} \mathrm{NPs}$} \\
\hline & Vehicle (Serine) & 100 & 200 & 400 \\
\hline Litters examined & 23 & 24 & 21 & 23 \\
\hline \multicolumn{5}{|l|}{ External examination } \\
\hline Fetuses examined & 338 & 368 & 310 & 340 \\
\hline Fetuses with malformations (\%) ${ }^{\mathrm{a}}$ & 0 & 0 & 0 & 0 \\
\hline Litters affected $(\%)^{b}$ & 0 & 0 & 0 & 0 \\
\hline Fetuses with variations, $\mathrm{n}(\%)^{\mathrm{a}}$ & $4(1.18)$ & $6(1.63)$ & I $(0.32)$ & $7(2.06)$ \\
\hline Litters affected, $n(\%)^{\mathrm{b}}$ & $4(17.39)$ & $6(25.00)$ & I (4.76) & $7(30.43)$ \\
\hline Hematoma & 4 & 6 & I & 7 \\
\hline
\end{tabular}

Notes: aA single fetus may be represented more than once in listing individual defects. 'lncludes litters with one or more affected fetuses. Abbreviations: bw, body weight; NPs, nanoparticles; $\mathrm{ZnO}^{\mathrm{SM20(+)}}, 20-\mathrm{nm}$ positively charged $\mathrm{ZnO}$.

$\mathrm{ZnO}^{\mathrm{SM} 20(+)} \mathrm{NP}$ treatment because the salivation was observed sporadically and was not dose dependent. This finding may attribute to irritation or stress of the test subjects. $\mathrm{ZnO}^{\mathrm{SM} 20(+)}$ NPs induced significant maternal toxicity in the $400-\mathrm{mg} / \mathrm{kg} /$ day group, which was evidenced by suppressed body-weight gain, decreased liver weight, and increased adrenal gland weights. The suppressed body-weight gain in the high-dose group could have been a direct effect of $\mathrm{ZnO}^{\mathrm{SM} 20(+)} \mathrm{NPs}$ on pregnant dams, because the gravid uterine weight of the $400-\mathrm{mg} / \mathrm{kg} /$ day group at term was similar to that of the control group.

In general reproductive toxicity studies, it is well known that body and organ weights could be sensitive indicators of potentially toxic chemicals. ${ }^{4-50}$ The significant decreases in the absolute liver weight in 400-mg/ $\mathrm{kg} /$ day group were attributed to the administration of $\mathrm{ZnO}^{\mathrm{SM} 20(+)} \mathrm{NPs}$, since these changes were remarkable in comparison with the control group, showing a clear-cut dose-response relationship. Earlier studies revealed that after uptake in the gastrointestinal tract, the biodistribution of engineered NPs was located at the liver and kidney. ${ }^{15,51,52}$ Significant weight increases of the adrenal glands were observed in the $400-\mathrm{mg} / \mathrm{kg} /$ day group, which could be considered as a treatment-related effect, since these changes was remarkably distinguishable in comparison with the control group. Previous studies demonstrated that the function and weight of adrenal glands is adversely effected by various stressful factors. ${ }^{53-56}$ So the increased weights of adrenal glands are also considered to be related to stress responses, induced by the administration of $\mathrm{ZnO}^{\mathrm{SM} 20(+)} \mathrm{NPs}$, which is consistent with the decreased body-weight gain in the group.

Up to now, several studies have evaluated the toxic effects of $\mathrm{ZnO}$ nanomaterials in vitro and in vivo. Yang et $\mathrm{al}^{57}$ demonstrated with primary mouse embryo fibroblast cells that the interrelationship existed between particle size, shape, chemical composition, and toxicology effects of carbon black, single-wall carbon nanotube, silicon dioxide, and ZnO NPs.

Table 8 Visceral alterations in fetuses from rats treated with $\mathrm{ZnO}^{\text {SM20(+) NPs }}$

\begin{tabular}{|c|c|c|c|c|}
\hline \multirow[t]{2}{*}{ Dose (mg/kg bw/day) } & \multicolumn{4}{|c|}{$\mathrm{ZnO}^{\mathrm{SM} 20(+)} \mathrm{NPs}$} \\
\hline & Vehicle ${ }^{\text {(Serine) }}$ & 100 & 200 & 400 \\
\hline Litters examined & 23 & 24 & 21 & 23 \\
\hline \multicolumn{5}{|l|}{ Visceral examination } \\
\hline Fetuses examined & 169 & 180 & 154 & 165 \\
\hline Fetuses with malformations (\%) & 0 & 0 & 0 & 0 \\
\hline Litters affected (\%) & 0 & 0 & 0 & 0 \\
\hline Fetuses with variations, $\mathrm{n}(\%)^{\mathrm{a}}$ & 7ㄱ (42.0I) & $85(47.22)$ & $70(45.45)$ & $69(4 \mid .82)$ \\
\hline Litters affected, $n(\%)^{b}$ & $19(82.61)$ & $24(100)$ & $21(100)$ & $20(86.96)$ \\
\hline Misshapen thymus & 11 & 12 & 12 & $32 * *$ \\
\hline \multicolumn{5}{|l|}{ Ureter abnormality } \\
\hline Grade III & 9 & 14 & 8 & $20 *$ \\
\hline Dilated renal pelvis & 0 & 0 & 0 & 2 \\
\hline Large kidney & 0 & 0 & 0 & 3 \\
\hline
\end{tabular}

Notes: ${ }^{\mathrm{A}} \mathrm{A}$ single fetus may be represented more than once in listing individual defects. ${ }^{\mathrm{b}}$ Includes litters with one or more affected fetuses. Statistically different from the vehicle control group; $* P<0.05, * * P<0.01$.

Abbreviations: bw, body weight; NPs, nanoparticles; $\mathrm{ZnO}^{\mathrm{SM20(+)}}, 20-\mathrm{nm}$ positively charged $\mathrm{ZnO}$. 
Table 9 Skeletal variations in fetuses from rats treated with $\mathrm{ZnO}^{\mathrm{SM20(+)}} \mathrm{NPs}$

\begin{tabular}{|c|c|c|c|c|}
\hline \multirow[t]{2}{*}{ Dose (mg/kg bw/day) } & \multicolumn{4}{|c|}{$\mathrm{ZnO}^{\mathrm{SM} 20(+)} \mathrm{NPs}$} \\
\hline & Vehicle (Serine) & 100 & 200 & 400 \\
\hline Litters examined & 23 & 24 & 21 & 23 \\
\hline \multicolumn{5}{|l|}{ Skeletal examination } \\
\hline Fetuses examined & 169 & 188 & 156 & 175 \\
\hline Fetuses with malformations, $\mathrm{n}(\%)^{\mathrm{a}}$ & $2(1.18)$ & $3(1.60)$ & $2(1.28)$ & $3(1.7 I)$ \\
\hline Litters affected, $n(\%)^{b}$ & $2(8.70)$ & $3(12.50)$ & $2(9.52)$ & $3(13.04)$ \\
\hline \multicolumn{5}{|l|}{ Thoracic centrum } \\
\hline Cleavage ossification & 2 & 3 & 2 & 3 \\
\hline Fetuses with variations, $\mathrm{n}(\%)^{\mathrm{a}}$ & $16(9.47)$ & $22(11.70)$ & $6(3.85)$ & I7 (9.7I) \\
\hline Litters affected, $n(\%)^{b}$ & II (47.83) & $13(54.17)$ & $5(23.8 I)$ & $9(39.13)$ \\
\hline \multicolumn{5}{|l|}{ Skull } \\
\hline Incomplete ossification & 0 & 0 & 0 & 1 \\
\hline \multicolumn{5}{|l|}{ Thoracic centrum } \\
\hline Dumbbell ossification & 4 & 3 & I & I \\
\hline Asymmetric & 1 & 2 & I & 0 \\
\hline Incomplete ossification & 4 & 12 & 3 & 4 \\
\hline \multicolumn{5}{|l|}{ Rib } \\
\hline Short rib & 0 & 0 & 0 & I \\
\hline Supernumerary & 5 & 5 & 1 & 6 \\
\hline \multicolumn{5}{|l|}{ Sternebra } \\
\hline Incomplete ossification & 2 & 0 & 0 & 4 \\
\hline
\end{tabular}

Notes: ${ }^{a} \mathrm{~A}$ single fetus may be represented more than once in listing individual defects. 'lncludes litters with one or more affected fetuses.

Abbreviations: bw, body weight; NPs, nanoparticles; $\mathrm{ZnO}^{\mathrm{SM20(+)}}, 20-\mathrm{nm}$ positively charged $\mathrm{ZnO}$.

Xia et $\mathrm{al}^{58}$ reported that $\mathrm{ZnO}$ induced toxicity in RAW 264.7 cell lines, leading to the generation of reactive oxygen species, oxidant injury, excitation of inflammation, and cell death. According to the bacterial toxicity study of $\mathrm{ZnO} N P s,{ }^{59} \mathrm{ZnO}$ NPs damaged bactericidal wall by increasing membrane permeability. In nematodes, ${ }^{60}$ the toxicity of manufactured $\mathrm{ZnO}$ NPs (1.5 nm) might have caused the intracellular biotransformation. Interestingly, comparable toxicities of nanoparticulate $\mathrm{ZnO}$, bulk $\mathrm{ZnO}$, and $\mathrm{ZnCl}_{2}$ were observed with algae. ${ }^{61}$

External and skeletal variations were found in few fetuses (Tables 7-9), as to morphological variation or malformation findings from the fetuses of $\mathrm{ZnO}^{\mathrm{SM} 20(+)} \mathrm{NP}$-treated dams. In particular, significant increases in the number of fetuses with visceral variations were observed in the $400 \mathrm{mg} / \mathrm{kg}$ of $\mathrm{ZnO}^{\mathrm{SM} 20(+)} \mathrm{NPs}$ group, which could be considered as a treatment-related effect, since these changes were remarkable in comparison with the control group. Significant increases in the number of fetuses with visceral variations were observed in the $400 \mathrm{mg} / \mathrm{kg} /$ day of $\mathrm{ZnO}^{\mathrm{SM} 20(+)} \mathrm{NPs}$ group, which may have not been a direct influence of the test substance. Increases in visceral variations (misshapen thymus and ureter abnormality) were also considered to be indirect effects of maternal toxicity or a spontaneous effect, because these changes were not significant, and the treatment-related fetal malformation was not found at all tested doses. The observed fetal variations in the present study were not considered to be caused by the administration of $\mathrm{ZnO}^{\mathrm{SM} 20(+)} \mathrm{NPs}$ since they occurred at a very low rate without exhibiting a dose-response relationship, or they were sporadically observed in fetuses from normal control rats. ${ }^{62-64}$

The concentration of $\mathrm{Zn}$ in the fetuses in the vehicle and $\mathrm{ZnO}^{\mathrm{SM} 20(+)} \mathrm{NP}$-dose groups are shown in Figure 1. Different distributions of NPs ingested into the body could be found at different regions due to their small size. After the exposure of $400 \mathrm{mg} / \mathrm{kg} /$ day of $\mathrm{ZnO}^{\mathrm{SM} 20(+)} \mathrm{NPs}$, a significant increase of $\mathrm{Zn}$ contents was not found in the $\mathrm{ZnO}^{\mathrm{SM} 20(+)} \mathrm{NP}$-treated rats in comparison with the control group. Although the increases in $\mathrm{Zn}$ concentrations in the exposed fetuses exhibited a trend, their influence on intrauterine fetal growth/development could be considered as weak effects.

In the present study, effects of $\mathrm{ZnO}^{\mathrm{SM} 20(+)} \mathrm{NPs}$ on intrauterine growth and on fetal visceral morphology were observed. Lower mean maternal body weights and body-weight gain in comparison to the control group were observed in the group treated with $400 \mathrm{mg} / \mathrm{kg} /$ day $\mathrm{ZnO}^{\mathrm{SM} 20(+)} \mathrm{NPs}$ in a dose-related manner. Lower mean corrected body weight was noted in this group at necropsy. Furthermore, the reduction in bodyweight gain during the late gestation period in the $400-\mathrm{mg} / \mathrm{kg} /$ day group was considered to be mainly due to the growth of fetuses, since the fetal weight was markedly decreased in this group. Similarly, decreased body-weight gain during the late gestation period was due to the decreased food consumption, 
which resulted in reduction of fetal weight in utero. On the contrary, some positive effects of other NPs were noted in similar reproduction/developmental toxicity studies. When silica and titanium dioxide NPs were administered to pregnant mice intravenously, pregnancy complications were observed. Mice also had smaller uteri and smaller fetuses than untreated controls. ${ }^{65}$ Also, when silicon crystal NPs $(50 \mathrm{mg} / \mathrm{kg})$ were injected, these NPs led to reduction in body-weight gain in pregnant rats and newborn rats at different stages of the experiment, but without noticeable effect on other parameters of physical development of rat progeny or teratogenic effects. ${ }^{66}$ In addition, oral administrations of silver NPs $(250 \mathrm{mg} / \mathrm{kg})$ caused a relatively low toxic effect. ${ }^{67}$

Unpublished 90-day repeated oral-dose and genotoxicity data from our previous studies are briefly summarized, as follows. The ZnO NPs did not cause any significant changes at the endpoints of repeated-dose toxicity, including clinical observation, functional observation, body-weight gain, water and food consumption, urinalysis, hematology, serum biochemistry, organ weight, toxicokinetic study, tissue distribution, and histopathology in the repeated study. In addition, when 14-day recovery groups were set for the high-dose groups in both sexes, no significant result was observed in functional examination, body-weight gain, water and food consumption, urinalysis, necropsy, and organ weight. Hence, it was concluded that no significant induced effect was affected by the treatment of the ZnO NPs. However, dosedependent depositions of $\mathrm{ZnO}$ NPs were also found in the pancreas, glandular stomach, and eyes, indicating potential systemic distributions of ZnO NPs in the mammalian tissues. Furthermore, genotoxicity tests of ZnO NPs did not show any gene mutation potential in vitro, chromosome aberration assay in vitro, or micronucleus test in vivo. Moreover, in vivo micronucleus test and in vivo comet assay in the 90-day study also indicated negative results, supporting that $\mathrm{ZnO}$ NPs did not cause any DNA damage.

\section{Conclusion}

In summary, prenatal and developmental toxicity of positively charged $\mathrm{ZnO}$ NPs were tested in accordance with the OECD test guideline 414 and GLP principle. Pregnant female rats were orally treated with $\mathrm{ZnO}^{\mathrm{SM} 20(+)} \mathrm{NPs}$, from GD 5-19, with doses of 100, 200, and $400 \mathrm{mg} / \mathrm{kg} / \mathrm{day}$. The results of this developmental toxicity study suggest that administration of $\mathrm{ZnO}^{\mathrm{SM} 20(+)} \mathrm{NPs}$ to pregnant rats had minimal impact on intrauterine fetal growth and development, even in the high dose of $400 \mathrm{mg} / \mathrm{kg} /$ day. Based on the results of these studies, a dosage level of $200 \mathrm{mg} / \mathrm{kg} /$ day of $\mathrm{ZnO}^{\mathrm{SM} 20(+)}$
NPs was considered the no-observed-adverse-effect level for both maternal toxicity and embryo-fetal development. Although the result of the current study clearly showed the adverse effects of $\mathrm{ZnO}^{\mathrm{SM} 20(+)} \mathrm{NPs}$ on pregnant rats and fetuses, information on the effects of $\mathrm{ZnO}$ NPs on reproduction/ development are not sufficient at this time.

\section{Acknowledgment}

This research was supported by a grant (10182MFDS991) from the Ministry of Food \& Drug Safety in 2010-2011.

\section{Disclosure}

The authors report no conflicts of interest in this work.

\section{References}

1. Clarence SY, Geoffrey SS, Sunny EI. Nanoparticles toxicity and their of exposures. Pak J Pharm Sci. 2012;25(2):477-491.

2. Hernandezbattez $\mathrm{AB}$, Gonzalez R, Viesca JL, et al. $\mathrm{CuO}, \mathrm{ZrO}_{2}$ and $\mathrm{ZnO}$ nanoparticles as antiwear additive in oil lubricants. Wear. 2008;265(3-4):422-428.

3. Schilling K, Bradford B, Castelli D, et al. Human safety review of "nano" titanium dioxide and zinc oxide. Photochem Photobiol Sci. 2010;9(4):495-509.

4. Gerloff K, Albrecht C, Boots AW, Förster I, Schins RP. Cytotoxicity and oxidative DNA damage by nanoparticles in human intestinal Caco-2 cells. Nanotoxicology. 2009;3(4):355-364.

5. Jin T, Sun D, Su JY, Zhang H, Sue HJ. Antimicrobial efficacy of zinc oxide quantum dots against Listeria monocytogenes, Salmonella Enteritidis, and Escherichia coli O157:H7. J Food Sci. 2009;74(1): M46-M52.

6. He L, Liu Y, Mustapha A, Lin M. Antifungal activity of zinc oxide nanoparticles against Botrytis cinerea and Penicillium expansum. Microbiol Res. 2011;166(3):207-215.

7. Rasmussen JW, Martinez E, Louka P, Wingett DG. Zinc oxide nanoparticles for selective destruction of tumor cells and potential for drug delivery applications. Expert Opin Drug Deliv. 2010;7(9):1063-1077.

8. John S, Marpu S, Li J, et al. Hybrid zinc oxide nanoparticles for biophotonics. J Nanosci Nanotechnol. 2010;10(3):1707-1712.

9. US Department of Health and Human Services. Toxicological profile for zinc. Atlanta, Georgia: US Department of Health and Human Services, Agency for Toxic Substances and Disease Registry; 2005. Available from: http://www.atsdr.cdc.gov/toxprofiles/tp60.pdf. Accessed November 27, 2014.

10. Drinker P, Thomason RM, Finn JL. Metal fume fever: therehold doses of zinc oxide, preventive measures, and the chronic effects of repeated exposure. J Industrial Hygiene. 1927;9:331-345.

11. Balance $\mathrm{P}$, Wong $\mathrm{H}$, Bernstein MS, Boushey HA. An experimental human model of metal fume fever. Ann Intern Med. 1991;114:930-936.

12. Baek M, Chung HE, Yu J, et al. Pharmacokinetics, tissue distribution, and excretion of zinc oxide nanoparticles. Int J Nanomedicine. 2012;7:3081-3097.

13. Metal Oxide Nanostrutures and Their Applications. Chapter 4. ZnO Nanoparticles: Growth, Properties, and Applications. 2010;1-36.

14. Wang L, Wang L, Ding W, Zhang F. Acute toxicity of ferric oxide and zinc oxide nanoparticles in rats. J Nanosci Nanotechnol. 2010;10(12):8617-8624.

15. Wang J, Zhou G, Chen C, et al. Acute toxicity and biodistribution of different sized titanium dioxide particles in mice after oral administration. Toxicol Lett. 2007;168(2):176-185.

16. Wang B, Feng W, Wang M, et al. Acute toxicological impact of nano-and submicro-scaled zinc oxide powder on healthy adult mice. J Nanopart Res. 2008;10(2):263-276. 
17. Surekha P, Kishore AS, Srinivas A, et al. Repeated dose dermal toxicity study of nano zinc oxide with Sprague-Dawley rats. Cutan Ocul Toxicol. 2012;31(1):26-32.

18. Yan G, Huang Y, Bu Q, et al. Zinc oxide nanoparticles cause nephrotoxicity and kidney metabolism alterations in rats. J Environ Sci Health A Tox Hazard Subst Environ Eng. 2012;47(4):577-588.

19. LuX, Liu Y, Kong X, Lobie PE, Chen C,Zhu T. Nanotoxicity: a growing need for study in the endocrine system. Small. 2013;9(9-10):1654-1671.

20. Iavicoli I, Fontana L, Leso V, Bergamaschi A. The effects of nanomaterials as endocrine disruptors. Int J Mol Sci. 2013;14:16732-16801.

21. Yamashita K, Yoshioka Y. [Safety assessment of nanomaterials in reproductive developmental filed]. Yakugaku Zasshi. 2012;132(3):331-335. Japanese.

22. OECD Guidelines for Testing of Chemicals section 4: Test No. 414, Prenatal and Developmental Toxicity Study [website on the Internet]. Paris: OECD; 2001. Available from: http://www.oecdilibrary.org/environment/test-no-414-prenatal-development-toxicitystudy_9789264070820-en. Accessed November 27, 2014.

23. OECD. Principle of Good Laboratory Practice. Paris: OECD; 1997. Available from: http://www.oecd.org/officialdocuments/ displaydocumentpdf $/ ? \operatorname{cote}=\mathrm{env} / \mathrm{mc} / \mathrm{chem}(98) 17 \&$ doclanguage $=e n$. Accessed November 27, 2014.

24. MFDS. GLP principle by Ministry of Food and Drug Safety (MFDS Gosi 2013-40. MFDS. Available from: http://www.mfds.go.kr/index.do? mid $=1013 \&$ division $=\&$ searchkey $=$ title $\% 3$ Acontents \&searchword $=\%$ $\mathrm{BA} \% \mathrm{~F} 1 \% \mathrm{C} 0 \% \mathrm{D} 3 \% \mathrm{BB} \% \mathrm{~F} 3 \& \mathrm{x}=0 \& \mathrm{y}=0$. Accessed December 5, 2014. Korean.

25. Degen A, Kosec M. Effect of $\mathrm{pH}$ and impurities on the surface charge of zinc oxide in aqueous solution. J Eur Ceram Soc. 2000;20:667-673.

26. Oh JM, Park DH, Choy JH. Integrated bio-inorganic hybrid systems for nano-forensics. Chem Soc Rev. 2011;40(2):583-595.

27. Kim K-M, Kim T-H, Kim H-M, et al. Colloidal Behaviors of $\mathrm{ZnO}$ Nanoparticles in Various Aqueous Media. Toxicol Environ Health Sci. 2012;4(2):121-131.

28. Chung H, Yu J, Baek M, et al. Toxicokinetics of zinc oxide nanoparticles in rats. J Phys Conf Ser. 2013;429:012037.

29. Yamada T, Hara M, Ohba Y, Inoue T, Ohno H. [Studies on implantation traces in rats. II. Staining of cleared uteri, formation and distribution of implantation traces]. Jikken Dobutsu. 1985;34(3):249-260. Japanese.

30. Menegola E, Broccia ML, Giavini E. Atlas of rat fetal skeleton double stained for bone and cartilage. Teratology. 2001;64(3):125-133.

31. Wilson JG. Methods for administering agents and detecting malformations in experimental animals. Teratology: Principles and Techniques. 1965:262-277.

32. Suzuki M, Murakami U, Tabuchi A. Abstracts of papers presented at the thirteenth annual meeting of the congenital anomalies research association of Japan. Hiroshima, Japan, July 12-13, 1973. Teratology. 1973;8(1):83-111.

33. Chahoud I, Buschmann J, Clark R, et al. Classification terms in developmental toxicology: need for harmonization 1. Reprod Toxicol. 1999;13(1):77-82.

34. Makris SL, Solomon HM, Clark R, et al. Terminology of developmental abnormalities in common laboratory mammals (version 2). Congenit Anom (Kyoto). 2009;49(3):123-246.

35. Weil CS. Selection of the valid number of sampling units and a consideration of their combination in toxicological studies involving reproduction, teratogenesis or carcinogenesis. Food Cosmet Toxicol. 1970;8(2):177-182.

36. Scheffe $\mathrm{H}$. A method for judging all contrasts in the analysis of variance*. Biometrika. 1953;40(1-2):87-110.

37. Kruskal WH, Wallis WA. Use of ranks in one-criterion variance analysis. Journal of the American Statistical Association. 1952;47:583-621.

38. Fisher RA. Statistical methods for research workers. Oliver and Boyd; 1970.

39. Bryant PL, Schmid JE, Fenton SE, Buckalew AR, Abbott BD. Teratogenicity of 2,3,7,8-tetrachlorodibenzo-p-dioxin (TCDD) in mice lacking the expression of EGF and/or TGF-alpha. Toxicol Sci. 2001;62(1):103-114.
40. Sharma V, Singh P, Pandey AK, Dhawan A. Induction of oxidative stress, DNA damage and apoptosis in mouse liver after sub-acute oral exposure to zinc oxide nanoparticles. Mutat Res. 2012;745(1-2):84-91.

41. Esmaeillou M, Moharamnejad M, Hsankhani R, Tehrani AA, Maadi H. Toxicity of $\mathrm{ZnO}$ nanoparticles in healthy adult mice. Environ Toxicol Pharmacol. 2013;35(1):67-71.

42. Miller RJ, Lenihan HS, Muller EB, Tseng N, Hanna SK, Keller AA. Impacts of metal oxide nanoparticles on marine phytoplankton. Environ Sci Technol. 2010;44(19):7329-7334.

43. Sinha R, Karan R, Sinha A, Khare SK. Interaction and nanotoxic effect of $\mathrm{ZnO}$ and $\mathrm{Ag}$ nanoparticles on mesophilic and halophilic bacterial cells. Bioresour Technol. 2011;102(2):1516-1520.

44. Wang HJ, Growcock AC, Tang TH, O’Hara J, Huang YW, Aronstam RS. Zinc oxide nanoparticle disruption of store-operated calcium entry in a muscarinic receptor signaling pathway. Toxicol In Vitro. 2010;24(7):1953-1961.

45. Ji S, Ye C. Synthesis, growth mechanism, and applications of zinc oxide nanomaterials. Journal of Materials Science and Technology. 2008;24(4):457-472.

46. Wang ZL. Zinc oxide nanostructures: growth, properties and applications. J Phys Condens Matter. 2004;16:R829.

47. Ajayan PM, Zhou OZ. Applications of carbon nanotubes. Topics in Applied Physics. 2001;80:391-425.

48. Andersen H, Larsen S, Spliid H, Christensen ND. Multivariate statistical analysis of organ weights in toxicity studies. Toxicology. 1999;136(2-3):67-77.

49. Bailey SA, Zidell RH, Perry RW. Relationships between organ weight and body/brain weight in the rat: what is the best analytical endpoint? Toxicol Pathol. 2004;32(4):448-466.

50. Chung MK, Kim CY, Kim JC. Reproductive toxicity evaluation of a new camptothecin anticancer agent, CKD-602, in pregnant/lactating female rats and their offspring. Cancer Chemother Pharmacol. 2007;59(3):383-395.

51. Chen Z, Meng H, Xing G, et al. Acute toxicological effects of copper nanoparticles in vivo. Toxicol Lett. 2006;163(2):109-120.

52. Cui Y, Liu H, Zhou M, et al. Signaling pathway of inflammatory responses in the mouse liver caused by $\mathrm{TiO} 2$ nanoparticles. $J$ Biomed Mater Res A. 2011;96(1):221-229.

53. Odio MR, Maickel RP. Comparative biochemical responses of rats to different stressful stimuli. Physiol Behav. 1985;34(4):595-599.

54. Kioukia-Fougia N, Antoniou K, Bekris S, Liapi C, Christofidis I, Papadopoulou-Daifoti Z. The effects of stress exposure on the hypothalamic-pituitary-adrenal axis, thymus, thyroid hormones and glucose levels. Prog Neuropsychopharmacol Biol Psychiatry. 2002;26(5):823-830.

55. Kim HY, Lee SB, Chung YH, et al. Evaluation of subchronic inhalation toxicity of dimethyl disulfide in rats. Inhal Toxicol. 2006;18(5):395-403.

56. Ulrich-Lai YM, Figueiredo HF, Ostrander MM, Choi DC, Engeland WC, Herman JP. Chronic stress induces adrenal hyperplasia and hypertrophy in a subregion-specific manner. Am J Physiol Endocrinol Metab. 2006;291(5):E965-E973.

57. Yang H, Liu C, Yang D, Zhang H, Xi Z. Comparative study of cytotoxicity, oxidative stress and genotoxicity induced by four typical nanomaterials: the role of particle size, shape and composition. J Appl Toxicol. 2009;29(1):69-78.

58. Xia T, Kovochich M, Liong M, et al. Comparison of the mechanism of toxicity of zinc oxide and cerium oxide nanoparticles based on dissolution and oxidative stress properties. ACS Nano. 2008;2(10):2121-2134.

59. Huang Z, Zheng X, Yan D, et al. Toxicological effect of ZnO nanoparticles based on bacteria. Langmuir. 2008;24(8):4140-4144.

60. Ma H, Bertsch PM, Glenn TC, Kabengi NJ, Williams PL. Toxicity of manufactured zinc oxide nanoparticles in the nematode Caenorhabditis elegans. Environ Toxicol Chem. 2009;28(6):1324-1330.

61. Franklin NM, Rogers NJ, Apte SC, Batley GE, Gadd GE, Casey PS. Comparative toxicity of nanoparticulate $\mathrm{ZnO}$, bulk $\mathrm{ZnO}$, and $\mathrm{ZnCl} 2$ to a freshwater microalga (Pseudokirchneriella subcapitata): the importance of particle solubility. Environ Sci Technol. 2007;41(24): 8484-8490. 
62. Morita H, Ariyuki F, Inomata N, et al. Spontaneous Malformations in Laboratory Animals: Frequency of External, Internal and Skeletal Malformations in Rats, Rabbits and Mice. Congenit Anom. 1987;27(2):147-206.

63. Hood RD. Handbook of developmental toxicology. Informa Healthcare; 1997.

64. Kim J, Lee S, Bae J, Park J, Kim Y, Chung M. Historical control data for developmental toxicity study in Sprague-Dawley rats. J Toxicol Public Health. 2001;17:83-90.

65. Yamashita K, Yoshioka Y, Higashisaka K, et al. Silica and titanium dioxide nanoparticles cause pregnancy complications in mice. Nat Nanotechnol. 2011;6(5):321-328.
66. Durnev AD, Solomina AS, Daugel-Dauge NO, et al. Evaluation of genotoxicity and reproductive toxicity of silicon nanocrystals. Bull Exp Biol Med. 2010;149(4):445-449. English, Russian.

67. Hong JS, Kim S, Lee SH, et al. Combined repeated-dose toxicity study of silver nanoparticles with the reproduction/developmental toxicity screening test. Nanotoxicology. 2014;8(4):349-362.
International Journal of Nanomedicine

\section{Publish your work in this journal}

The International Journal of Nanomedicine is an international, peerreviewed journal focusing on the application of nanotechnology in diagnostics, therapeutics, and drug delivery systems throughout the biomedical field. This journal is indexed on PubMed Central, MedLine, CAS, SciSearch $®$, Current Contents $® /$ Clinical Medicine,

\section{Dovepress}

Journal Citation Reports/Science Edition, EMBase, Scopus and the Elsevier Bibliographic databases. The manuscript management system is completely online and includes a very quick and fair peer-review system, which is all easy to use. Visit http://www.dovepress.com/ testimonials.php to read real quotes from published authors.

Submit your manuscript here: http://www.dovepress.com/international-journal-of-nanomedicine-journal 